\title{
Investigating the Cooling Effect of Living Walls in the Sunken Courtyards of Traditional Houses in Yazd
}

\author{
By \\ Fatemeh Vaezizadeh $^{1 *}$, Siavash Rashidisharifabad ${ }^{2}$, Reza Afhami ${ }^{3}$
}

\begin{abstract}
Studies on traditional Iranian houses have revealed that people used to construct buildings in a soil mass in order to reduce heat lossand decrease the cost of heating and cooling. Hence the residents could both use the excavated soil and proper thermal conditions by creating a microclimate. Over the past few years, green cover of buildings have been developed as useful and beneficial elements in designing ceilings and facades. This paper considers the cooling effect of three systems of living walls with the help of Design Builder simulation software in hot-dry climate (sunken courtyard of old houses in Yazd). The findings show that the thermal difference of inner surface between noncovered and plant-covered walls is significant in type 2 . In type 3 , thermal difference at night reaches 12 centigrade in some hours. Thermal difference in the three systems, changes from $2^{\circ} \mathrm{C}$ to at most $21^{\circ} \mathrm{C}$. Furthermore, the decrease of thermal changes is significant when living wall details are used (type 2 and 3). Given the results, the use of green architectural coating with different systems has a significant impact on the increase of the quality of interior air and consequently the decrease of cooling energy consumption.
\end{abstract}

Keywords: sunken courtyard; living wall; hot-dry region; cooling energy efficiency

\section{Introduction}

$64.66 \%$ of Iranian lands $(1046446 \mathrm{~mm})$ are located in arid and hyper-arid climate. Furthermore, many Iranian cities especially those with hot and arid climate have poor green cover. Moreover, in Iran especially in desert regions such as Yazd, there is too much of sun light and also the problems of thermal load and glare [1]. The establishment of proper environmental conditions for citizens with the least consumption of energy in buildings could bear a number of positive impacts on the protection of environment and environmental sustainability [2].

From different methods used for improving the interior condition of buildings, providing comfort for citizens and establishing sustainable environment, vertical green walls are the most importance and easy-to-access. The earth cooling effect, deep ground temperature and the advantages of green walls could be used, to attain the highest cooling effect. Green wall known generally as vertical gardens is a descriptive term that usually addresses the use of all plant forms on a vertical surface (even roof). It is also known as a part of green technology in our contemporary age. This method uses height

\footnotetext{
${ }^{1}$ Department of Art and Architecture, Kerman Branch, Islamic Azad University,Kerman, Iran.

${ }^{2}$ Department of Art and Architecture, Shahrbabak Branch, Islamic Azad University,Shahrbabak, Iran.

${ }^{3}$ Department of Art and Architecture, Tarbiat Modares university,Tehran, Iran.

*Corresponding Author: Tel: +989132956939,
} 
for the plants growth. This expression could be divided into two major categories of green facades and living walls[3]. Accordingly, there are three elements related to living walls: green facades, living walls and biological walls. Green facades refer to the establishment of climbing plants that root in ground on the surface of walls or a scaffolding pole. Living walls protect plants that root on wall surface or on the ground beneath the wall. Biological wall is a living wall or green facade that is built on the interior walls [4]. Compared to green facades, thermal features of living walls have their optimal performance when they are installed in extreme lighting condition. The highest light decrease and evaporation happen in walls that face direct light radiation. Their structure should be capable of protecting plants, soil and humidity. It should also have proper drainage [5]. This research focuses on the system of living walls.

This research suggests that heat island effect could have a lot of negative impacts on the urban citizens. The production and increase of urban heat waves affect the health, mortality and air pollution. To resist these negative impacts, the use of vertical green walls is strongly suggested [6]. Besides, in a research [7] focusing on the energy performance of three living wall samples in mild climate, it was shown that in sunny days, daily temperature range is between $12^{\circ} \mathrm{C}$ and $20^{\circ} \mathrm{C}$. As a matter of fact the use of architectural green cover significantly help the change of thermal properties in buildings and hence the loss of energy. [8] studied a living wall system in an experimental building and they found that during day hours, the interior temperature of living wall system is $20 \%$ less than wall with no plant cover. It was also found that the former had less thermal fluctuations. Accordingly, this research aims to provide more explanation on the decrease of energy consumption from the viewpoint of different types of living wall systems in dry and arid regions.

\section{Sample in arid climate}

\subsection{The physical properties of the building studied (Olumiha House in Yazd)}

Yazd geographical coordinates are $31^{\circ} 53^{\prime} 50^{\prime \prime}$ North, 54 $22^{\circ} 3^{\prime \prime}$ East with a $1230 \mathrm{~m}$ altitude, located in a cold and arid climate. Yazd has no humid season and is a typical example of dry and arid climate. This house is almost 150 years old. Generally speaking, the house is divided into three organized sections: 1) north eastern part of the house is a rectangular yard occupying south eastern, south western and north western spaces of the house. 2) The middle part includes a big yard with different spaces occupying the east, west and northwest of the yard, and a sunken courtyard is located at the center with various surrounding spaces. 3) The southern part of the house is a land that looks like an old garden. The whole building is in the shape of a rectangle, which is stretched from southeast to northeast [9]. 

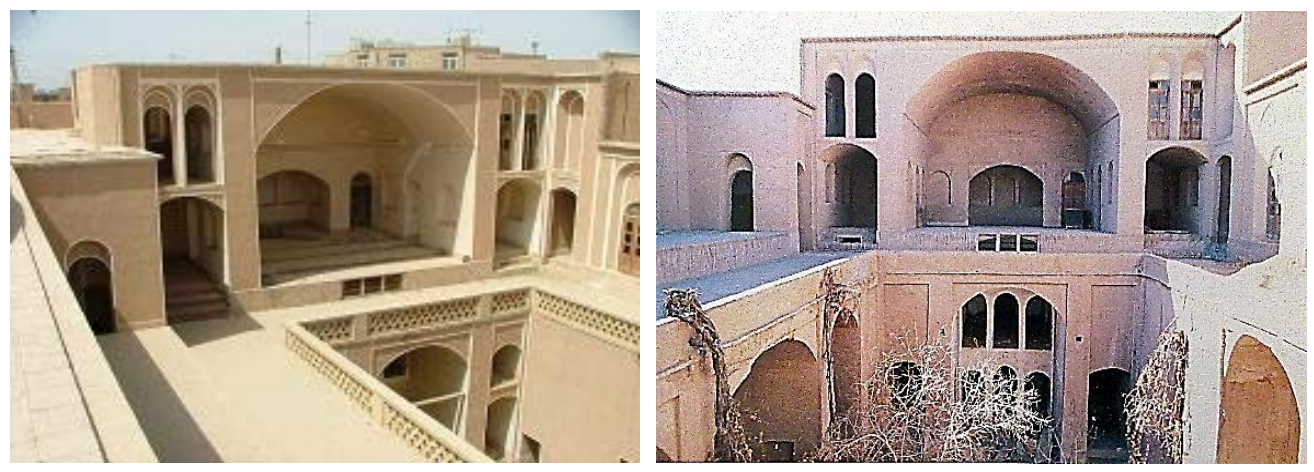

Figure 1.Olumiha House in Yazd [9]

\subsection{Sunken courtyard}

One of the most visible features of this house is the existence of sunken courtyard in the middle of the big yard. This sunken courtyard provides a center for the yard that is itself a central element in the house. Thus it organizes the center of the house design and deepens the yard space. The sunken courtyard had added a new space to the interior spaces of the yard, a space that is dependent despite being a part of the yard. Another impact of the sunken courtyard is the emergence of various views and perspectives in the yard. The existence of sunken courtyard is not limited to this house, but is observed in many traditional houses. However, it should be noted that the sunken courtyard is an independent yard in the main yard.

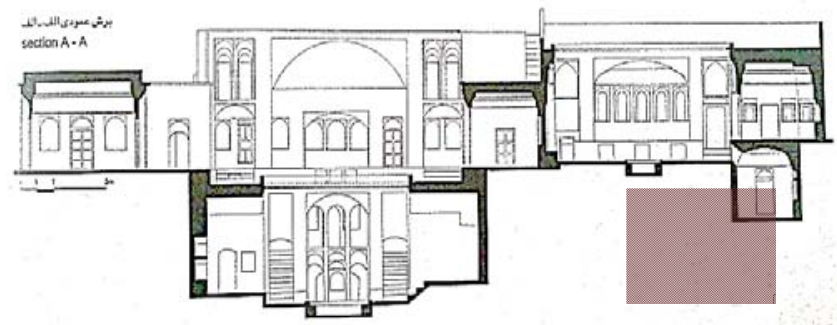

Figure2. The zone under study in simulation software (section) [9]

Some of the house spaces are located in the basement. In the north west of the house, the basement spaces are related in southwest and northwest. In the middle part, the majority of spaces surrounding the sunken courtyard belong to the basement. In this part, southeastern spaces are closed, and northwestern and southeastern spaces are semiopen [9]. The depth of these yards is more than normal with the goal of having access aqueducts and underground water resources. 
Figure3.The zone under study in simulation software (plan) [9]

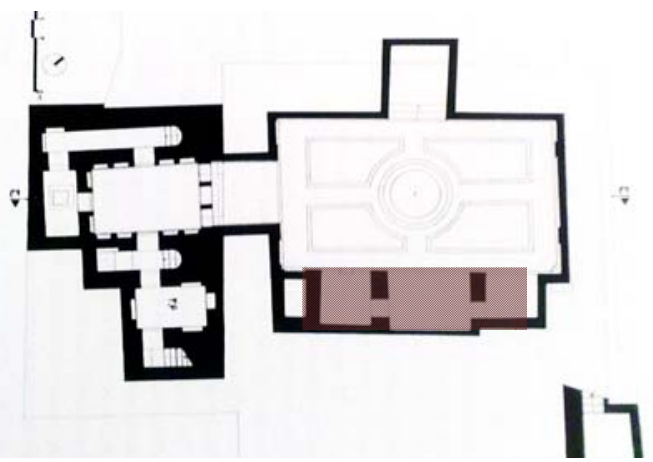

\subsection{Living walls}

These systems are improving across the world because living wall could be used in the form of green walls. They could also be utilized actively in building systems as biological filters and could directly affect ventilation in buildings. On the other hand, they can be used both inside and outside a building [10]. Living walls include modular systems of drainage and irrigation of plants in the form of vertical gardens with quick green cover for vertical surfaces. They are also a proper space for the uniform growth of plants [11]. Therefore, this quick green cover and their capability of being replaced and changed is their superiority for establishing green facades. Moreover, they are effective in improving the environment and ecological condition of buildings. The open space between metal structures and walls are completely covered by vertical and horizontal shadowing tool from top, south and north. Therefore, air layers are not heated by direct sun radiation and natural ventilation does not occur in this space. The following figure shows the details of a living wall system.

Figure4. Details of a living wall system [4]

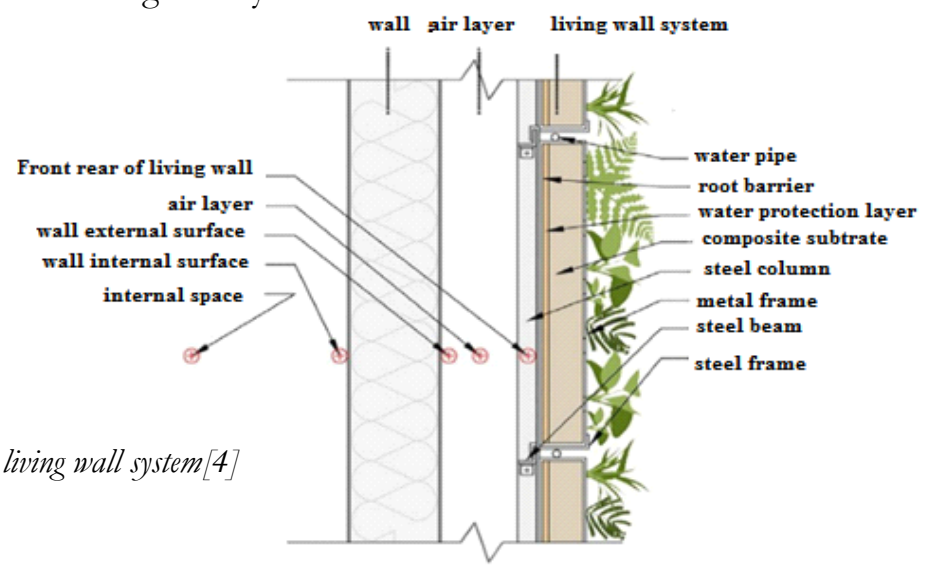

\section{Methodology}

3.1 Introduction of energy consumption simulation and estimation software (Design Builder 4.1) and research method

Design Builder is used for modeling of buildings from different perspectives such as the building physics (materials), architecture, cooling and heating systems. It is capable of modeling all aspects of a building. Except for the modeling heating and cooling in a building, the software is able to dynamically model buildings' energy 
consumption including thermal energy, light, hot water etc. Design Builder software uses the ecological profile of different Iranian cities to estimate the receiving, consumption and loss of energy precisely according to the location of the building in question. The role of this software becomes evident when the exertion of minor and major changes to the modeling and designing phases of a building affects the energy consumption or storage in the building.

This study focuses on three types of living wall systems, and the data on their systems, locations and position are presented. The analyses of all three systems took place in Yazd hot and arid climate and according to the mentioned case study which addresses Olumiha House's courtyard and basement. This made the ecological conditions the same for all of the three systems.

\subsection{Three types of living walls}

From among many types of living walls, three following types of such systems are scrutinized. Studies and simulations indicate that there are either living walls or ordinary walls.

\subsection{Type 1}

The first system is located on the southeastern walls, as shown in Figure 5. This living wall is consisted of layers expressed in Table 1. Living walls are installed on exterior walls made of bricks with $37 \mathrm{~cm}$ width forming exterior and interior plaster.

\section{Table 1.Detailsof the first type of living wall system[By authors]}

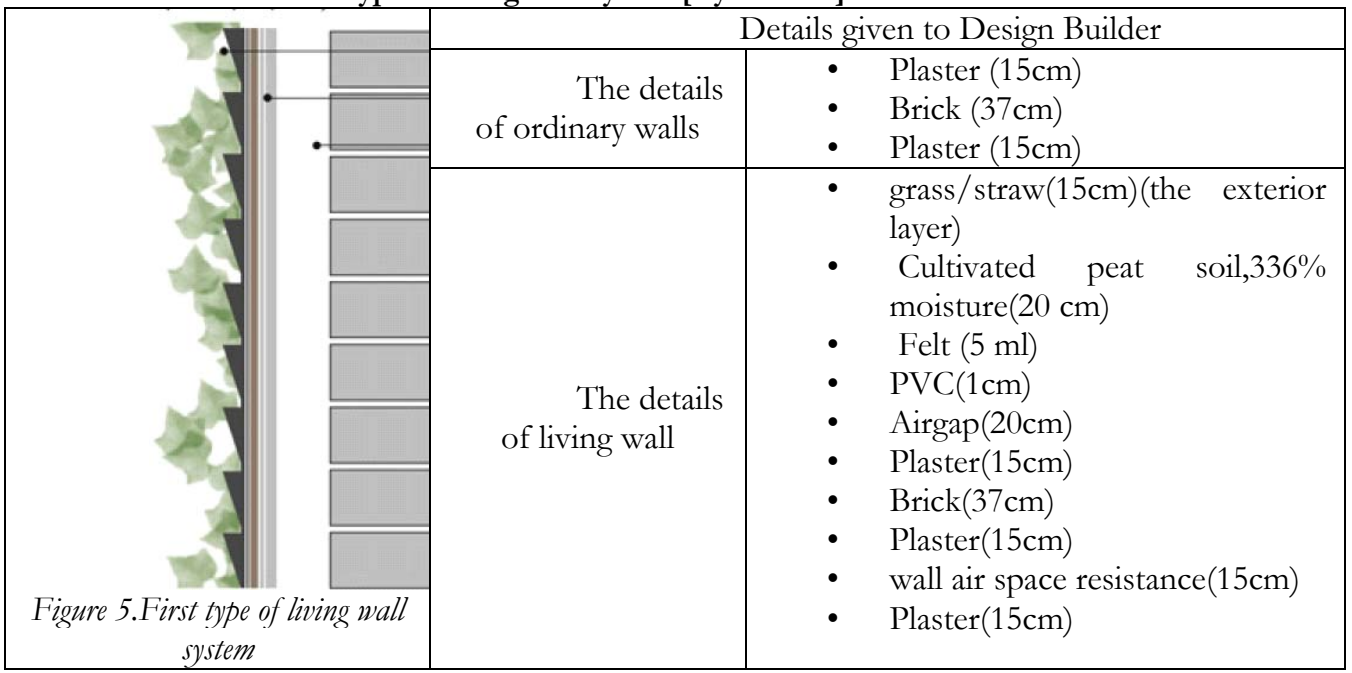

\subsection{Type 2}

The second system is located on the southeastern walls as could be observed in Figure 6. This living wall is consisted of layers shown in Table 2. The living walls are installed on exterior walls with no insulator with $17 \mathrm{~cm}$ width. 
Table 2.Detailsof the second type of living wall system[By authors]

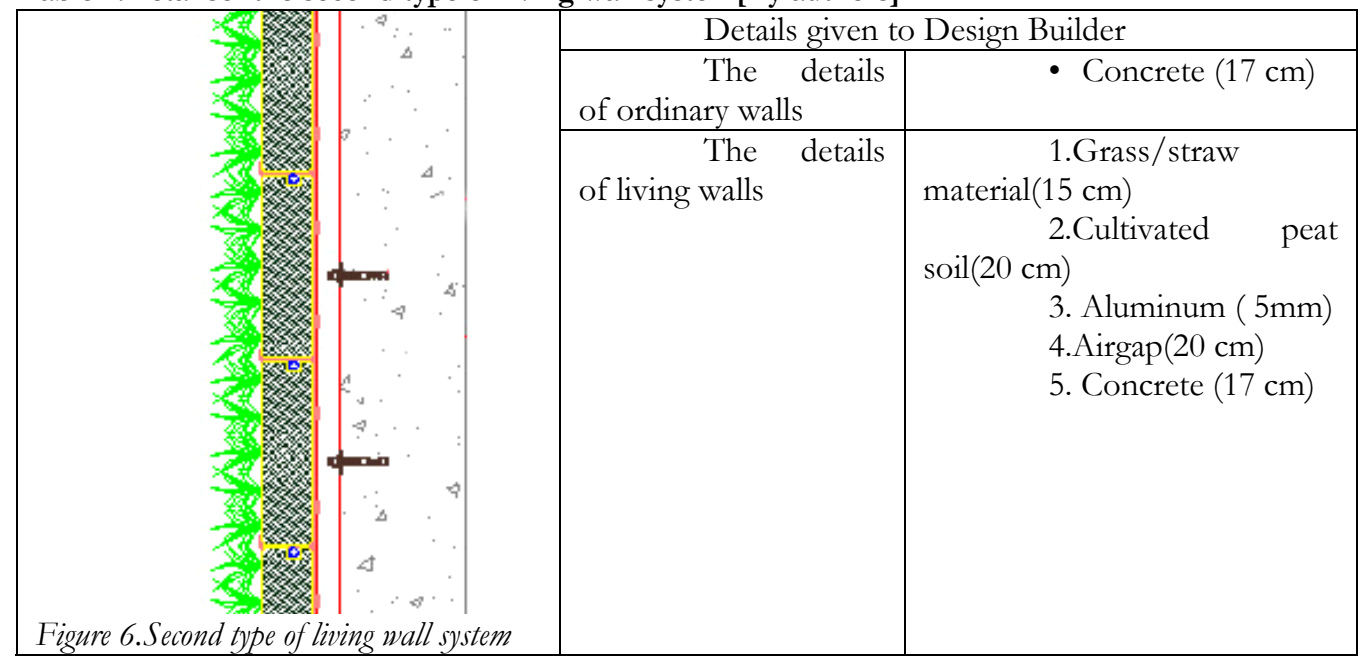

\subsection{Type 3}

As could be observed in Figure 7, the third system is consisted of a few layers as shown in Table 3 . The wall on which the third living wall system is installed is stony with a $16 \mathrm{~cm}$ width and with no insulator.

Table 3. Details of the third type of living wall system[By authors]

\begin{tabular}{|c|c|c|}
\hline \multirow{3}{*}{ The living wall stones } & \multicolumn{2}{|c|}{ Details given to Design Builder } \\
\hline & $\begin{array}{l}\text { The } \\
\text { details } \\
\text { ordinary walls }\end{array}$ & $\begin{array}{ll} & \text { Stone }(3 \mathrm{~cm}) \\
\text { - } & \text { Gravel }(10 \mathrm{~cm}) \\
\text { - } & \text { Stone }(3 \mathrm{~cm})\end{array}$ \\
\hline & $\begin{array}{l}\text { The } \\
\text { details of living } \\
\text { walls }\end{array}$ & $\begin{array}{ll}\text { - } & \text { grass } / \text { straw }(15 \mathrm{~cm}) \\
& \text { Cultivated } \\
& \text { soill,336\% moisture }(20 \\
& \mathrm{cm}) \\
\text { - } & \text { Stone }(3 \mathrm{~cm}) \\
\text { - } & \text { Gravel }(10 \mathrm{~cm}) \\
\text { - } & \text { Stone }(3 \mathrm{~cm})\end{array}$ \\
\hline Figure 7.Third type of living wall system & & \\
\hline
\end{tabular}

\section{Findings and Discussion}

In order to analyze the cooling impact of living walls on the reduction of temperature, the three types of living wall systems were studied. Since sun radiation is an ecological factor affects the behavior of living walls, the hottest day of year in summer was under the consideration. Therefore, the condition of equivalent temperature inside 
building (the mean temperature inside a building and the temperature the person feels) and walls surface temperature compared to outside temperature was analyzed.

\subsection{The procedure for evaluating different types of systems in simulation software}

As could be observed in Table 4, different hours of the hottest day of year in summer were selected for the three systems. The obtained information for each system given the details received by the software is as follows:

\subsection{The first type of living wall systems}

The data derived from Design Builder software in different hours of a day show the difference between temperatures of two alternatives (without using the details of living walls- using the details of living walls). Graph 1 (alternative 1) shows that the temperatures of exterior surface at $10,12,14$ and $8 \mathrm{pm}$ were respectively $67^{\circ} \mathrm{C}, 85^{\circ} \mathrm{C}$, $93^{\circ} \mathrm{C}$ and $68^{\circ} \mathrm{C}$. In these hours the temperatures of interior surface were respectively $31^{\circ} \mathrm{C}, 32^{\circ} \mathrm{C}, 33^{\circ} \mathrm{C}$ and $33^{\circ} \mathrm{C}$. However, in the second alternative, the first type of living wall system is used, and as Graph 2 shows, the temperatures of the exterior wall surface

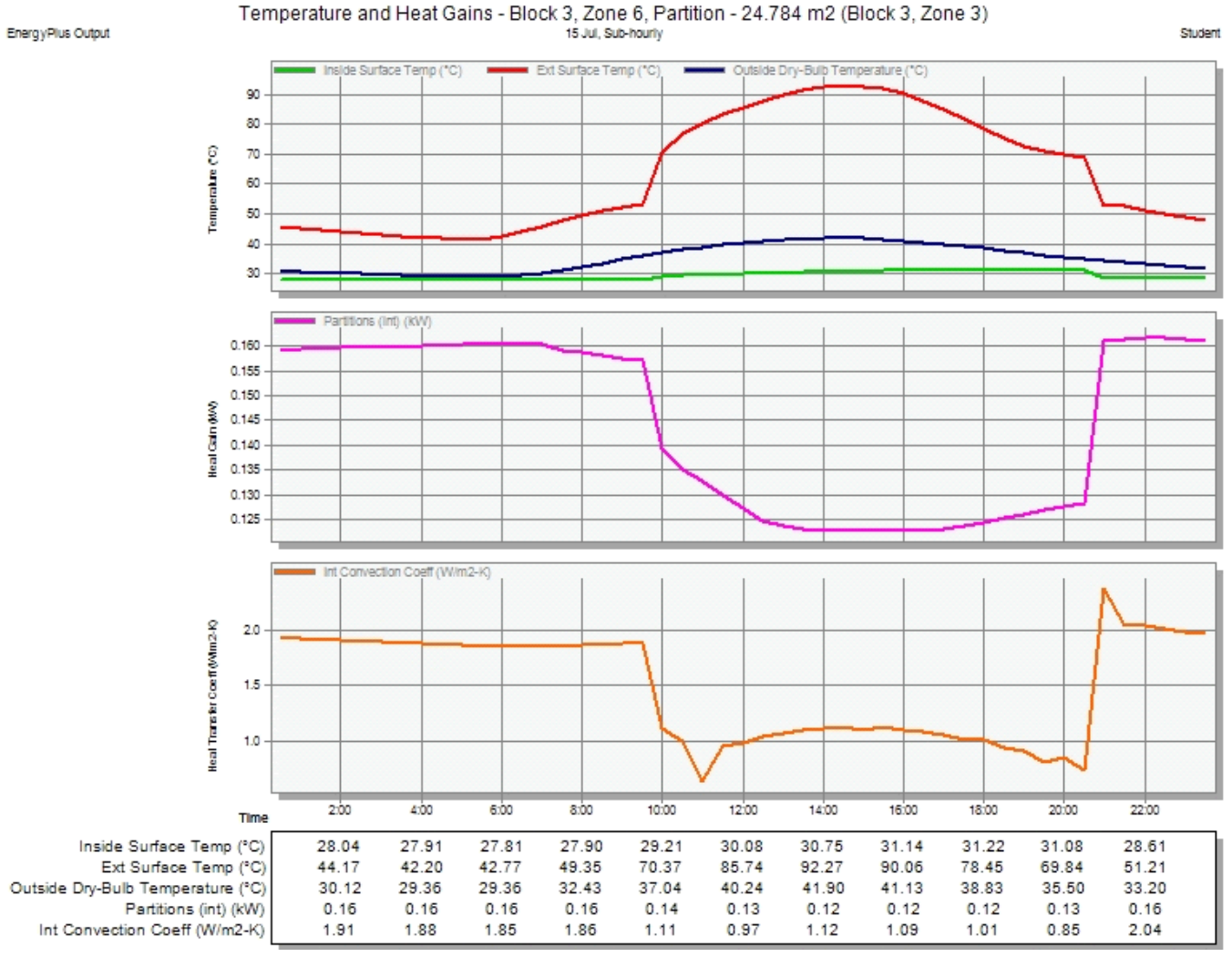

Graph 1.First system type-Alternative 1 (no living wall) 
in the mentioned hours were respectively $70^{\circ} \mathrm{C}, 85^{\circ} \mathrm{C}, 92^{\circ} \mathrm{C}$ and $69^{\circ} \mathrm{C}$, and the temperatures of interior surface were respectively $29^{\circ} \mathrm{C}, 30^{\circ} \mathrm{C}, 30^{\circ} \mathrm{C}$ and $31^{\circ} \mathrm{C}$.

It is evident that given the same temperature of the exterior surface in the two alternatives, the temperature of the interior surface in different hours is $2-3^{\circ} \mathrm{C}$ less in the plant-covered walls.

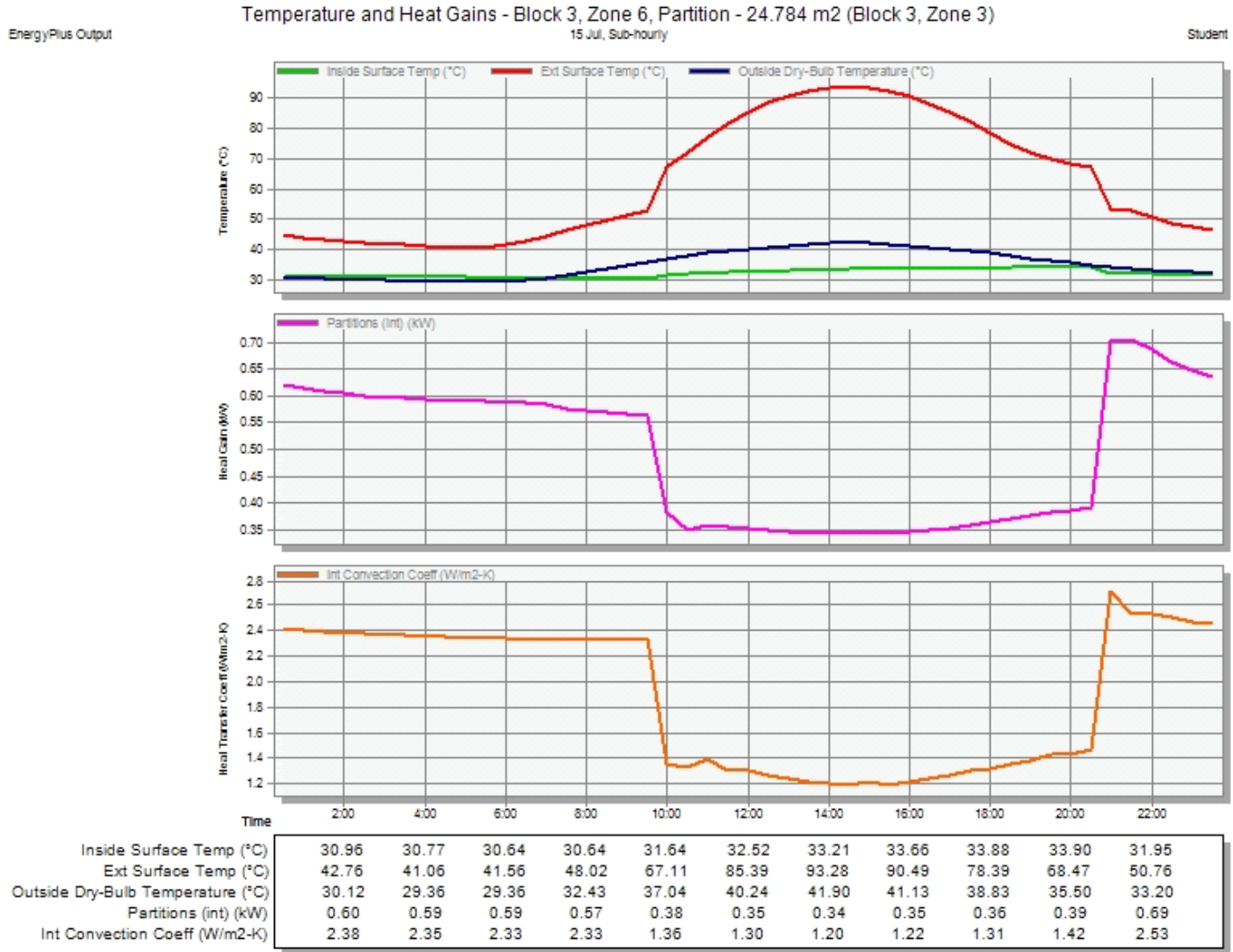

Graph 2. First system type-Alternative 2 (using living wall)

\subsubsection{The second type of living wall system}

The analysis of the second type of system also took place in the hottest day of year in summer. The data obtained by the software show the difference in the temperature of the interior wall surface in the two modeled alternatives as could be observed in Graph3 and 4. The temperatures of exterior surface at 10,12, 14 and $8 \mathrm{pm}$ were respectively $47^{\circ} \mathrm{C}, 58^{\circ} \mathrm{C}, 64^{\circ} \mathrm{C}$ and $59^{\circ} \mathrm{C}$ in the first alternative. In these hours the temperatures of interior surface were respectively $37^{\circ} \mathrm{C}, 41^{\circ} \mathrm{C}, 46^{\circ} \mathrm{C}$ and $53^{\circ} \mathrm{C}$. In the second alternative, the second type of living wall system is used, and the temperatures of the exterior wall surface in the mentioned hours were respectively $57^{\circ} \mathrm{C}$, $67^{\circ} \mathrm{C}, 74^{\circ} \mathrm{C}$ and $69^{\circ} \mathrm{C}$, and the temperatures of interior surface were respectively $30^{\circ} \mathrm{C}$, $31^{\circ} \mathrm{C}, 31^{\circ} \mathrm{C}$ and $32^{\circ} \mathrm{C}$ 


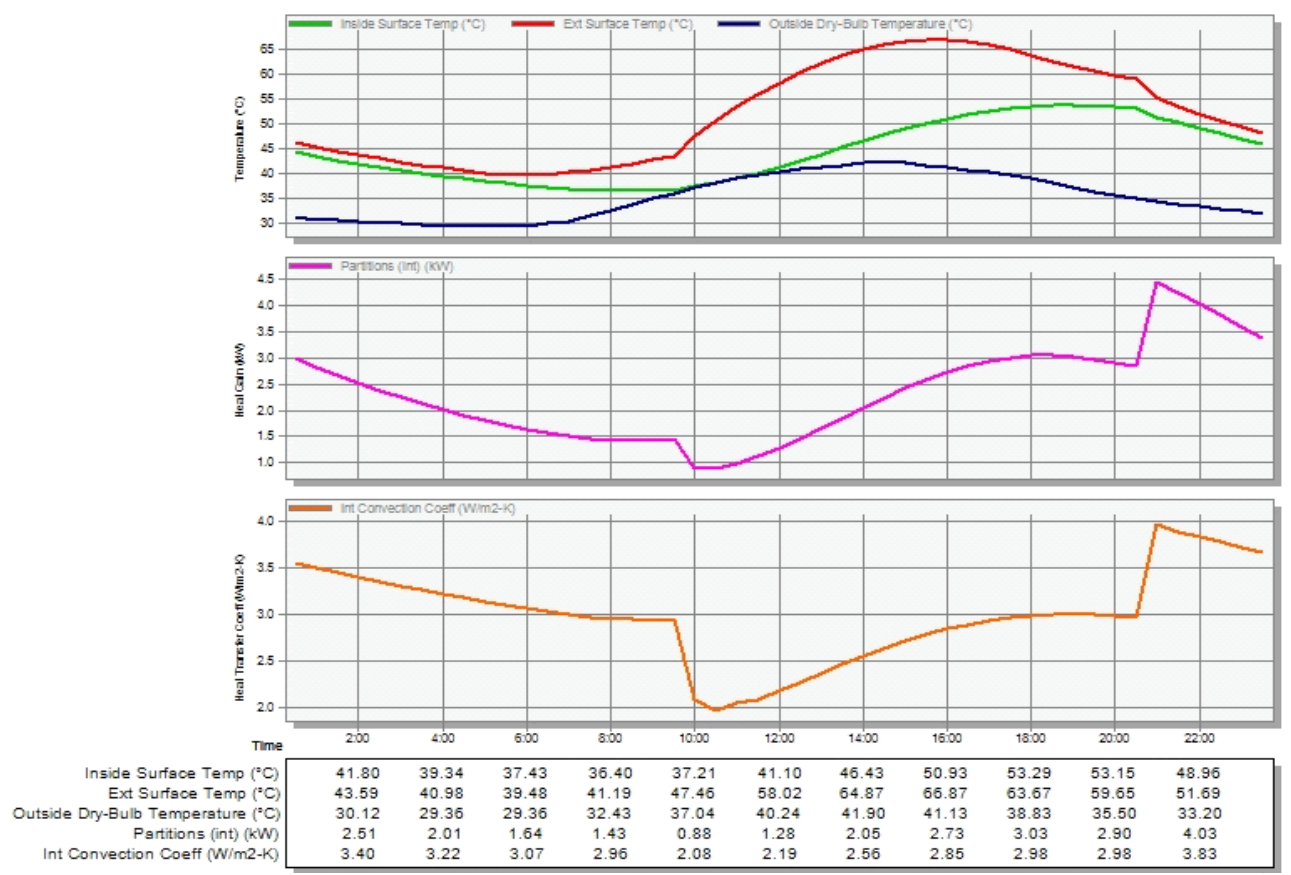

Graph 3. Second type of system-Alternative 1 (ordinary wall with no plant cover)

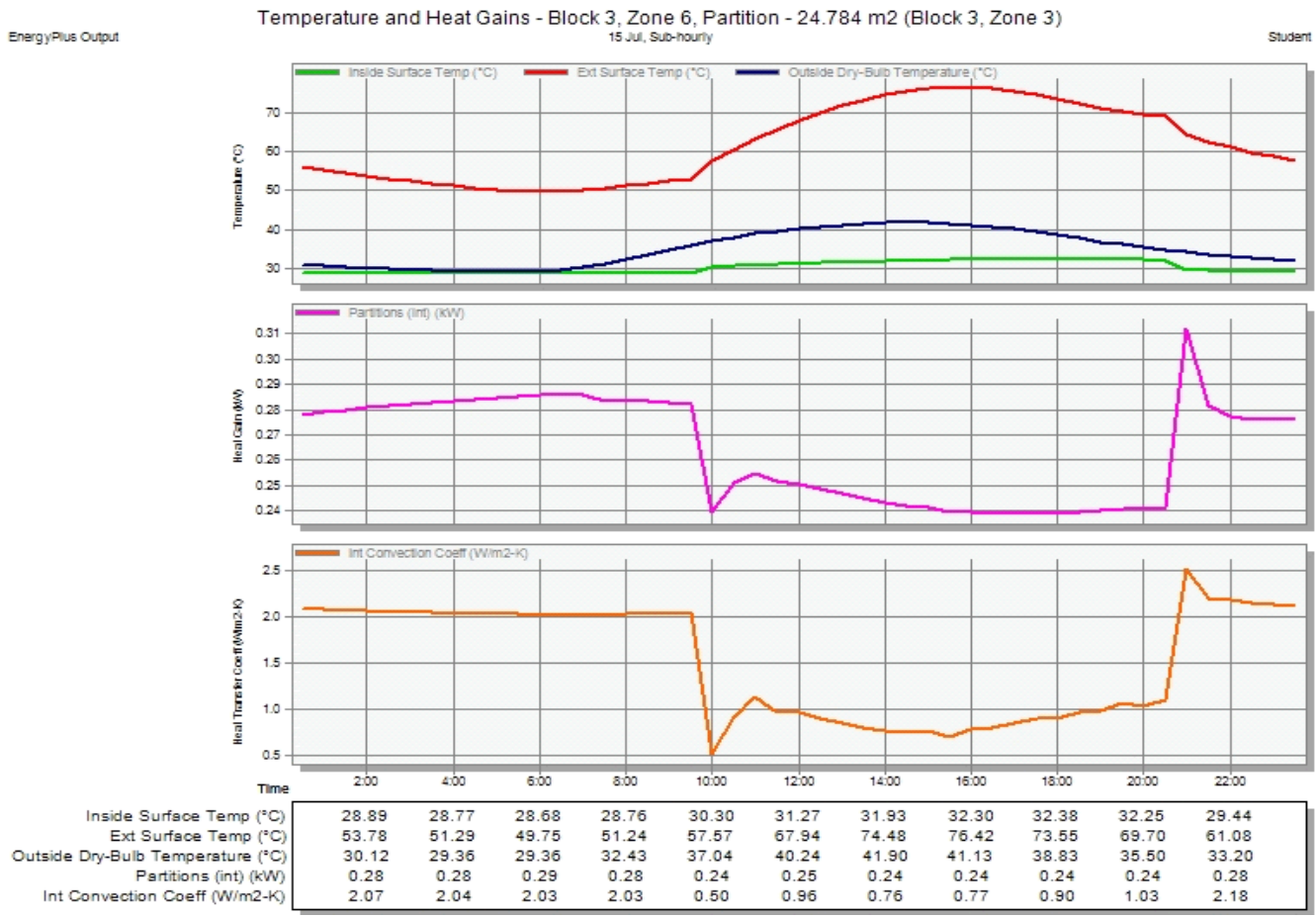

Graph 4. Second type of system-Alternative 2 (wall with plant cover)

(C) 2016 The Author. Journal Compilation ～（C) 2016 European Center of Sustainable Development. 
The difference between the temperature of the ordinary wall and the plant-covered wall is $21^{\circ} \mathrm{C}$ as shown in the figures; the interior surface temperature in alternative two is less due to the use of living wall system. However, the temperature of the exterior wall surface covered with plant is more than the surface of the ordinary wall in all hours; the difference between the temperature of exterior wall surface of the ordinary wall and the living wall is almost $10^{\circ} \mathrm{C}$.

\subsubsection{The third type of system}

The data derived from the analysis of the third type of system in the hottest day of year in summer show the difference in the temperature of the interior wall surface in the two modeled alternatives as could be observed in Graph5 and 6 . The temperatures of exterior surface at $10,12,14$ and 8 pm were respectively $51^{\circ} \mathrm{C}, 68^{\circ} \mathrm{C}, 78^{\circ} \mathrm{C}$ and $67^{\circ} \mathrm{C}$ in the first alternative. In these hours the temperatures of interior surface were respectively $32^{\circ} \mathrm{C}, 34^{\circ} \mathrm{C}, 37^{\circ} \mathrm{C}$ and $44^{\circ} \mathrm{C}$. In the second alternative, the third type of living wall system is used, and the temperatures of the exterior wall surface in the mentioned hours were respectively $58^{\circ} \mathrm{C}, 73^{\circ} \mathrm{C}, 83^{\circ} \mathrm{C}$ and $72^{\circ} \mathrm{C}$, and the temperatures of interior surface were respectively $30^{\circ} \mathrm{C}, 31^{\circ} \mathrm{C}, 31^{\circ} \mathrm{C}$ and $32^{\circ} \mathrm{C}$.

As could be observed from the figures, it is evident that the temperature of ordinary wall exterior surface is $5^{\circ} \mathrm{C}$ more than the temperature of plant-covered wall exterior surface. The opposite pattern could be observed in the temperature of the interior surface. The difference in the temperature of interior surface of the living wall and the ordinary wall is $3-12^{\circ} \mathrm{C}$. The temperature of the living wall interior surface is less than that of alternative one during daily hours. As a matter of fact, the plant covered wall had a greater tendency to temperature decrease, a pattern that is observable both in the first and the second type of systems as well. 


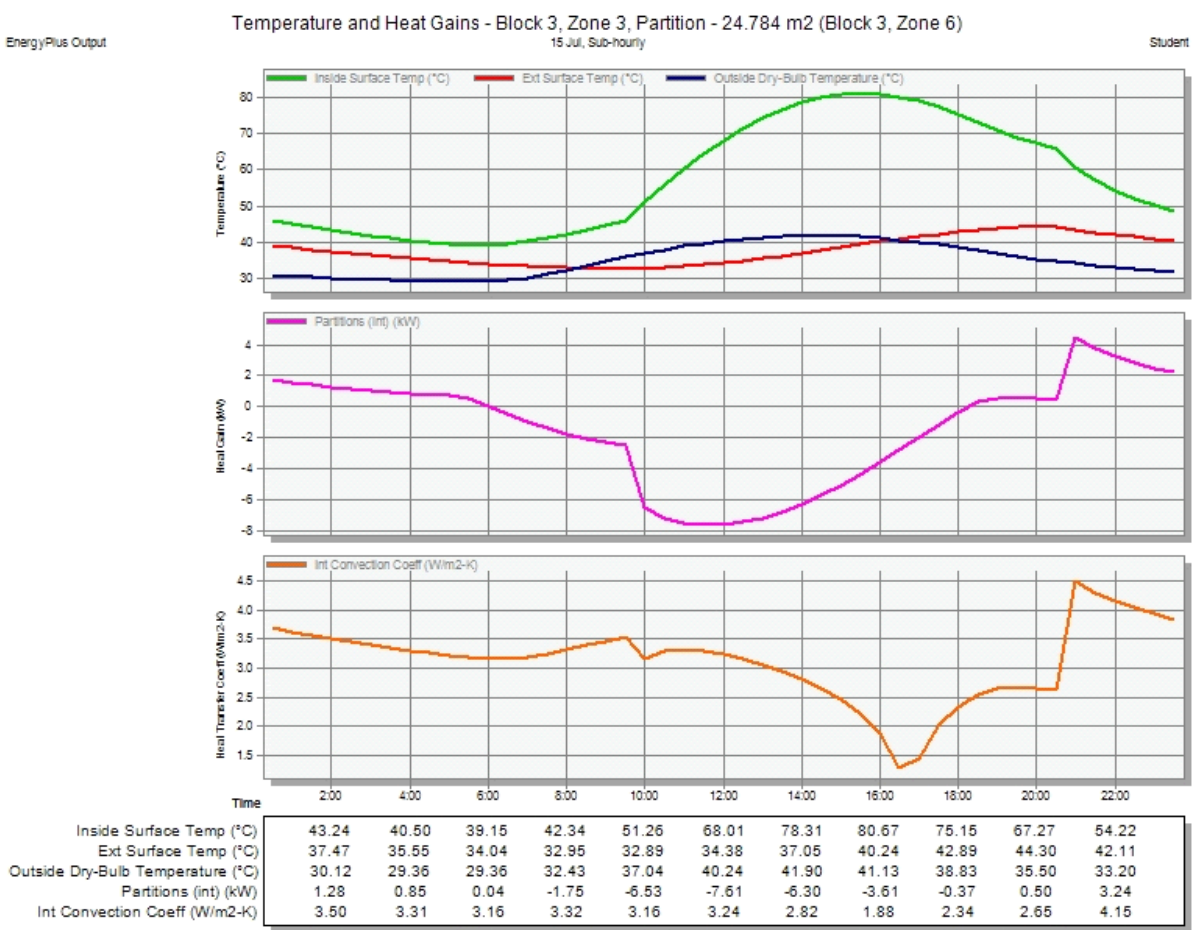

Graph 5. Third type of system - Alternative 1 (wall with no plant cover)

Temperature and Heat Gains - Block 3, Zone 3, Partition - 24.784 m2 (Block 3, Zone 6)

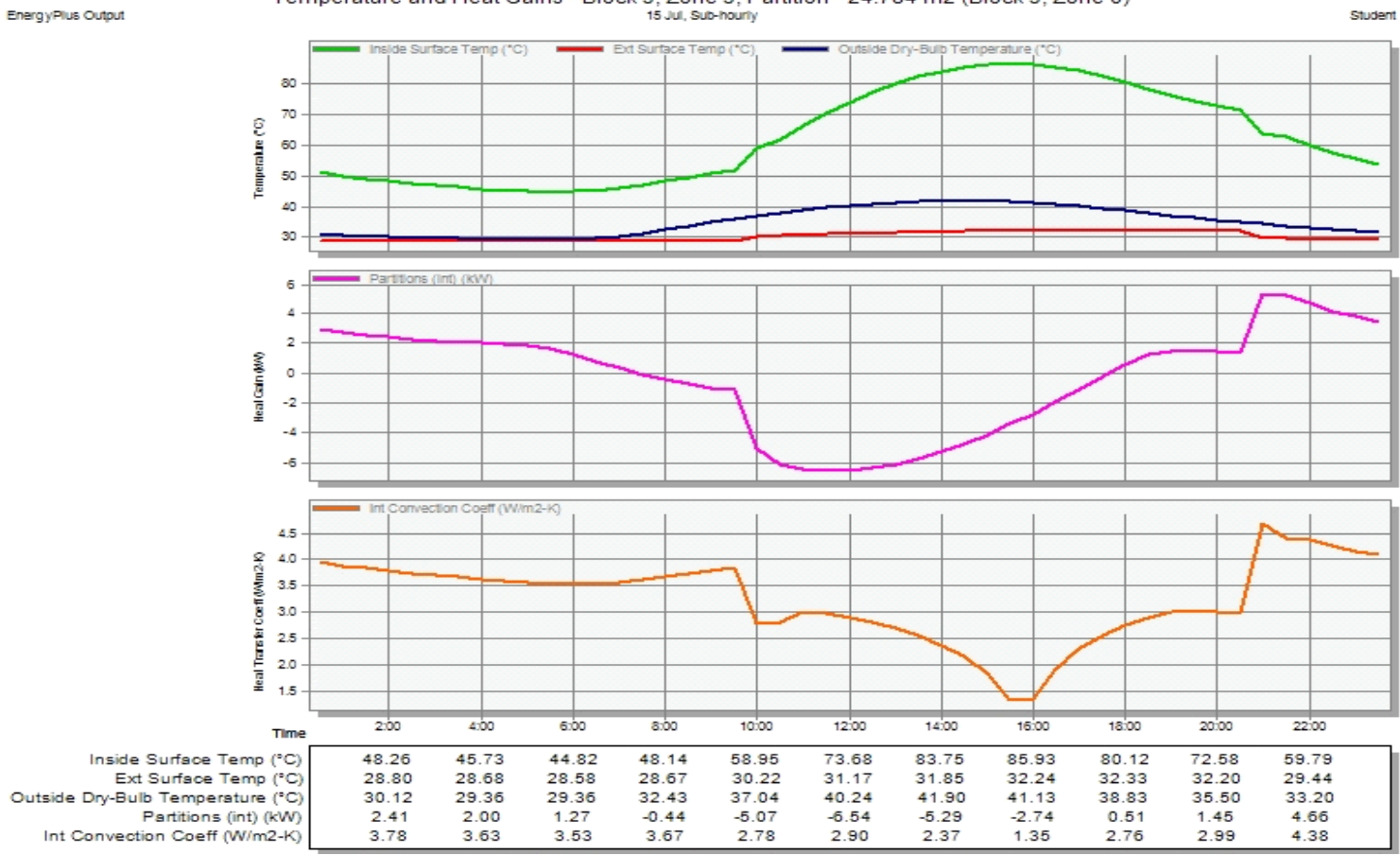

Graph 6. Third type of system - Alternative 2 (wall with plant cover)

(C) 2016 The Author. Journal Compilation $\quad$ (C) 2016 European Center of Sustainable Development. 


\subsection{The comparison of the three system types}

As could be observed in Table 4, the difference between the temperatures of interior surface in the two alternatives is more significant in the second type of system; in the third type, temperature difference in daily hours is at most $12^{\circ} \mathrm{C}$. In fact, temperature decrease of interior surface in the three types of systems ranges from $2^{\circ} \mathrm{C}$ in type 1 to $21^{\circ} \mathrm{C}$ in type 2 . Furthermore, given the obtained results, the decrease of temperature fluctuations is observable in type 2 and 3 in alternative 2 which uses plantcovered walls.

Table 4.The comparison of the three system types[By authors]

\begin{tabular}{|c|c|c|c|c|}
\hline $\begin{array}{l}\text { Three } \\
\text { types of } \\
\text { wall } \\
\text { systems }\end{array}$ & Alternatives & $\begin{array}{l}\text { The comparison of } \\
\text { temperature of } \\
\text { interior and exterior } \\
\text { surface in the two } \\
\text { alternatives }\end{array}$ & $\begin{array}{l}\text { Temperature } \\
\text { difference of the } \\
\text { wall exterior } \\
\text { surface (centigrade) }\end{array}$ & $\begin{array}{l}\text { Temperature } \\
\text { difference of the } \\
\text { wall interior } \\
\text { surface (centigrade) }\end{array}$ \\
\hline \multirow[t]{2}{*}{ Type 1} & $\begin{array}{l}\text { Walls with no } \\
\text { plant cover }\end{array}$ & $\begin{array}{l}\text { The higher } \\
\text { temperature of the } \\
\text { interior surface } \\
\text { during daily hours }\end{array}$ & \multirow[t]{2}{*}{ Almost equal } & \multirow[t]{2}{*}{$2-3^{\circ} \mathrm{C}$} \\
\hline & $\begin{array}{l}\text { Walls with } \\
\text { plant cover }\end{array}$ & & & \\
\hline \multirow{2}{*}{ Type 2} & $\begin{array}{l}\text { Walls with no } \\
\text { plant cover }\end{array}$ & $\begin{array}{l}\text { The higher } \\
\text { temperature of the } \\
\text { interior surface } \\
\text { during daily hours }\end{array}$ & \multirow{2}{*}{$10^{\circ} \mathrm{C}$} & \multirow{2}{*}{$21^{\circ} \mathrm{C}$} \\
\hline & $\begin{array}{l}\text { Wall } \\
\text { s with plant } \\
\text { cover }\end{array}$ & $\begin{array}{l}\text { The higher } \\
\text { temperature of the } \\
\text { exterior surface } \\
\text { during daily hours }\end{array}$ & & \\
\hline \multirow{2}{*}{ Type 3} & $\begin{array}{l}\text { Wall } \\
\text { s with no } \\
\text { plant cover }\end{array}$ & $\begin{array}{l}\text { The higher } \\
\text { temperature of the } \\
\text { interior surface } \\
\text { during daily hours }\end{array}$ & \multirow{2}{*}{$5^{\circ} \mathrm{C}$} & \multirow{2}{*}{$\begin{array}{c}3-12^{\circ} \mathrm{C} \\
\text { during daily hours }\end{array}$} \\
\hline & $\begin{array}{l}\text { Wall } \\
\text { s with plant } \\
\text { cover }\end{array}$ & $\begin{array}{l}\text { The higher } \\
\text { temperature of the } \\
\text { interior surface } \\
\text { during daily hours }\end{array}$ & & \\
\hline
\end{tabular}

\section{Conclusion}

When a structure or building is constructed with no excavation, the contact area between the building and the ground is equal to the total area of the building. However, when excavation is done, the contact area increases. Therefore, in hot and arid regions, buildings are constructed in soil mass to decrease thermal exchange in buildings and to reduce the cost by using natural ways of cooling and heating. To obtain the utmost cooling impact and to reduce the energy consumption in buildings constructed in soil 
mass, the use of living wall technology is very useful since it changes the thermal patterns of buildings and consequently it reduces the loss of cooling energy. In wall with no plant cover, the exterior surface of walls receives heat through direct sun radiation, diffuse sky radiation, radiation reflected from the earth, radiant heat exchange with the surroundings and convective heat exchange with environment. In living wall system condition, the system could deflect the extensive sun radiation which is the major factor in receiving heat by buildings. As a matter of fact, walls are affected via the microclimate between a wall surface and living wall system, in which walls are always losing heat to microclimates.

In this research, three types of living wall systems were evaluated under equal temperature and climatic condition with the goal of providing precise explanation on the cooling impact of living walls in hot and arid regions. The findings show that the difference between the temperatures of wall interior surface in the two alternatives is more significant in the second type of system. In the third type, temperature difference interior surface in daily hours is at most $12^{\circ} \mathrm{C}$. In fact, temperature decrease of interior surface in the three types of systems ranges from $2^{\circ} \mathrm{C}$ in type 1 to $21^{\circ} \mathrm{C}$ in type 2 . Furthermore, the decrease of temperature fluctuations is observable in type 2 and 3 in alternative 2 which uses plant-covered walls. In other words, the systems have shown similar patterns under the same climatic conditions in terms of reducing the temperature of interior surfaces. Given the findings, it can be stated that the use of living wall technology with different systems could be an important factor in reducing the temperature of surfaces in a building, decreasing the consumption of cooling energy, increasing energy storage.

\section{References}

Kazem Zade M, Tahbaz M. Measurement and analyzing daylight condition in traditional Kerman houses(Aminian house). Journal of Fine Arts 2013; 18: 17-26.

Nicol JF, Humphreys MA. Adaptive thermal comfort and sustainable thermal standards for buildings. Journal of Energy and buildings 2002; 34: 563-571.

Alud H. Modeling the Urban Heat Island Benefits of Green Roofs ion Toronto. In Proc. of 1st North American Green Roof Conference on Greening Rooftops for Sustainable communities, Chicago; 2003.

Chen Q, Li B, Liu X. An experimental evaluation of the living wall system in hot and humid climate. Energy and building 2013; 61: 298-302.

Wong NH, Kwang T, Alex Y. Thermal evaluation of vertical greenery systems for building walls. Building and Environment 2010; 45, 3: 663-672.

Clarke JF. Some effects of the urban structure on heat mortality. Environmental Research 1972; 5, 1: 93104.

Mazzali U, Peron F. et al. Experimental investigation on the energy performance of LivingWalls in a temperate climate. Building and Environment 2013; 64: 57-66.

Olivieri F, Neila FJ, Bedoya C. Energy saving and environmental benefits of metal box vegetal facades, in: Management of Natural Resources. Sustainable Development and Ecological Hazards II 2010; 127: 325-335.

Khovi HD.Ganjnameh Cyclopaedia of Iranian Islamic Architecture,Yazd Houses. University of Shahid Beheshti Press, Tehran, Iran; 2004. 
Eumorfopoulou EA, Kontoleon KJ. Experimental approach to the contribution of plant-covered walls to the thermal behaviour of building envelopes. Building and Environment 2009; 44: 1024-1038.

Wismer S. Living wall, a Feasibility study for SLC, WAT green. Waterloo; 2013. 